\title{
EVALUATION OF ANTICANCER POTENTIAL OF ETHANOLIC EXTRACT OF ALANGIUM SALVIFOLIUM LEAVES IN ANIMAL MODELS
}

\section{PRATHIMA C ${ }^{1 *}$, SHASHIKUMARA ${ }^{2}$, THIPPESWAMY T ${ }^{3}$}

\begin{abstract}
${ }^{1}$ Department of Pharmacology, JSS Medical College, JSS Academy of Higher Education and Research, Mysuru, Karnataka, India.
${ }^{2}$ Department of Pharmacology, Chamarajanagar Institute of Medical College, Yadapura, Karnataka, India. ${ }^{3}$ Department of General Medicine, JSS Medical College, JSS Academy of Higher Education and Research, Mysuru, Karnataka, India. Email: prathimac@jssuni.edu.in
\end{abstract} Received: 08 September 2018, Revised and Accepted: 02 November 2018

\section{ABSTRACT}

Objective: The present study aims to evaluate the anticancer potential of ethanolic extract of Alangium salvifolium leaves (EASL) against Ehrlich ascites carcinoma (EAC) in animal model.

Methods: The ethanolic extract of A. salvifolium was prepared by continuous method using Soxhlet apparatus. Phytochemical analysis of EASL was conducted. Anticancer activity of the extract was evaluated by EAC model in Swiss albino mice. EASL was administered at the doses of 100 and $200 \mathrm{mg} / \mathrm{kg}$ body weight once a day orally for 14 days, after $24 \mathrm{~h}$ of tumor inoculation.

Results: A. salvifolium leaves extract treatment produced significant decrease in tumor volume and body weight, and increase in total and nonviable cell count, along with elevated life span of EAC-bearing mice. The EASL exhibited potent dose-dependent antitumor activity. Further, the altered hematological parameters such as red blood cells, hemoglobin, and white blood cells levels as well as biochemical parameters such as serum glutamic oxaloacetic transaminase, serum glutamate pyruvate transaminase, alkaline phosphatase, albumin, and total protein levels in EAC mice were significantly $(\mathrm{p}<0.05)$ regained following treatment with EASL. The anticancer potential of EASL can be attributed to the presence of phenols and flavonoids.

Conclusion: Results suggest that EASL possesses significant anticancer activity against EAC tumor-bearing Swiss albino mice.

Keywords: Anticancer, Alangium salvifolium, Ehrlich ascites carcinoma.

(c) 2019 The Authors. Published by Innovare Academic Sciences Pvt Ltd. This is an open access article under the CC BY license (http://creativecommons. org/licenses/by/4. 0/) DOI: http://dx.doi.org/10.22159/ajpcr.2019.v12i2.29601

\section{INTRODUCTION}

Cancer is one of the most life-threatening diseases and a serious public health problem in both developed and developing countries. It is one of the leading causes of mortality worldwide. Cancer is a group of diseases characterized by the deregulated proliferation of abnormal cells that invade and disrupt surrounding tissues [1]. The reports from the International Agency for Cancer Research in 2008 indicated that there are approximately 12 million new cancer cases every year with 7 million cancer deaths within 5 years of diagnosis and about 25 million persons are living with cancer [2]. By 2030, it is estimated that there will be 26 million new cases diagnosed and 17 million cancer deaths annually [3]. Increasing interest and research on herbal medicine have revealed its importance in treating many diseases including cancer [4].

In the treatment of cancer, many synthetic and chemotherapeutic agents developed show various side effects such as alopecia, skin eruptions, reduced immunity, and secondary carcinogenesis [5]. Furthermore, there are treatment failures due to genetic mutations, drug resistance, etc. [5]. Hence, there is a need to develop newer, effective, and less toxic anticancer therapies. Ancient Indian medicinal science which was based on the natural products of plant origin was known to be effective against many cancers. Various medicinal plants are widely used in India as folk remedies or by different indigenous systems of medicine against different types of cancers. At present, research on anticancer drug development is largely focused on exploring potential phytochemicals [6].

Alangium salvifolium (Alangiaceae) is a small tree or shrub used as folk remedies in different indigenous systems of medicine such as Siddha, Unani, and Ayurveda and is native to South India, China, the Philippines, and Ceylon. The plant A. salvifolium has alternate leaves usually unequal about 12.5-17 cm long, 2.5-7.0 cm broad, oblong-lanceolate or oblongoval, acute or rounded at base, more or less acuminate, and obtuse at apex with 3-6 pairs of very oblique veins which are prominent beneath with white or yellowish-white fragrant flowers [7]. The different extracts of A. salvifolium contain phenolic compounds, flavonoids, alkaloids (ipecac and benzopyridoquinolizidine) carbohydrates, amino acids and volatile oil, alangine, lamarckinine, markindine, and emetine, tetrahydroisoquinoline monoterpene glycosides, phenolic glycosides, salviifosides A-C, salicin, kaempferol, and kaempferol 3-O-b-D-glucopyranoside [7].

The plant is known to possess various pharmacological activities such as antibacterial, antifungal, anti-inflammatory, antifertility, and antianxiety [7]. The chloroform extract of the flowers of A. salvifolium is known to possess antioxidant and anticancer activities [8]. Methanolic extract of $A$. salvifolium is known to possess significant antitumor activity in potato tumor assay [9]. Ethanolic extracts of A. salvifolium also exhibited protective role against CCL4-induced hepatic damage by its free radical scavenging property [10]. Hence, the present study was undertaken to evaluate the anticancer potential of the ethanolic extract of A. salvifolium leaves (EASL) by in vivo EAC model in Swiss albino mice.

\section{METHODS}

Plant materials and preparation of drug solution

A. salvifolium leaves were collected from Bannari Hill (Dhimbam), Coimbatore district, Tamil Nadu state, and it was authenticated by Dr. Mrutyunjaya (Prof, Dept. of Pharmacognosy, JSS Pharmacy College, Mysore). The leaves were subjected to wash with $70 \%$ alcohol and made into coarse powder after a shade dry for 1 week. About $500 \mathrm{~g}$ of 
this powder was subjected to Soxhlet extraction for $12 \mathrm{~h}$ using ethanol as a solvent under suitable temperature. The extract was further concentrated using vacuum extractor for complete removal of the ethanol (absolute, $\geq 99.5 \%$ ). The concentrated ethanolic EASL was used to evaluate the anticancer activity. Stock solution was freshly prepared using normal saline as solvent before dosing from which the different doses were administered by selecting the appropriate concentration.

\section{Phytochemical screening}

The freshly prepared extract of the leaves of A. salvifolium was subjected to phytochemical screening tests for the detection of various constituents [11].

\section{Chemicals}

The chemicals, ethanol, normal saline, phosphate-buffered saline, trypan blue dye and cisplatin were obtained from the indicated commercial sources. All the reagents used were of analytical reagent grade.

\section{Animals}

Swiss albino mice weighing 25-30 g of either sex were procured from the Central Animal Facility of the Institute and maintained under the standard conditions: Room temperature $(25 \pm 3)^{\circ} \mathrm{C}$, humidity $45-55 \%$, and $12 / 12 \mathrm{~h} \mathrm{light/dark}$ cycle. They were fed with commercially available mouse pellet diet and water was allowed ad libitum. The experimental protocols were approved by the Institutional Animal Ethical Committee of JSS Medical College, Mysuru (261/PO/ReBi/2000/CPCSEA), and procedures in this study were performed in accordance with guidelines of Committee for the Purpose of Control and Supervision of Experiments on Animals.

\section{Acute toxicity study}

According to OECD 423 guidelines, healthy adult male Swiss albino mice starved overnight were divided into six groups $(n=12)$ and were orally fed with increasing doses of EASL. Total EASL administered orally in doses of up to $2000 \mathrm{mg} / \mathrm{kg}$ did not produce any sign of toxicity and mortality in mice when observed for 14 days after administration. Based on preliminary toxicity study, the dose of our further study was determined between 100 and $300 \mathrm{mg} / \mathrm{kg}$.

\section{Animal grouping and treatment schedule}

Animals $(\mathrm{n}=12)$ were randomly divided into six groups and received respective drugs $24 \mathrm{~h}$ after EAC transplantation:

- Group 1: Normal group was treated with normal saline $(10 \mathrm{ml} / \mathrm{kg})$ without EAC cells

- Group 2: Control group was treated with normal saline $(10 \mathrm{ml} / \mathrm{kg})$ with EAC cells

- Group 3: Test Group-I - standard group treated with drug cisplatin (3.5 mg/kg i.p.)

- Group 4: Test Group-II - EASL (100 mg/kg p.o)

- Group 5: Test Group-III - EASL (200 mg/kg p.o)

- Group 6: Test Group-IV - cisplatin (1.75 mg/kg i.p.) + EASL (100 mg/kg p.o).

\section{Ehrlich ascites carcinoma (EAC)-induced tumor model}

Tumor cells

EAC cells obtained from JSS College of Pharmacy, Mysore, Karnataka, India. The procured EAC cells were maintained by intraperitoneal inoculation of $2 \times 10^{6}$ cells/mouse. EAC cells aspirated from the peritoneal activity of mice were washed with saline and were injected intraperitoneally to induce ascitic fluid tumor in the test group animals.

\section{Transplantation of EAC}

All the animals were injected with EAC cells $\left(0.2 \mathrm{ml}\right.$ of $2 \times 10^{6}$ cells $/$ mouse $)$ intraperitoneally except the normal group, for the development of ascites tumor [12]. After $24 \mathrm{~h}$ of tumor inoculation, the extracts of A. salvifolium in variable doses of $100 \mathrm{mg} / \mathrm{kg}$ and $200 \mathrm{mg} / \mathrm{kg}$ were administered once daily for 14 days to Groups IV-VI. After the last dose and $24 \mathrm{~h}$ of fasting, six mice from each group were sacrificed. Other animals in the groups were maintained with food and water ad libitum for survival studies.

\section{Tumor growth response}

The anticancer effect of EASL was assessed by tumor volume, increase in body weight, total and non-viable cell count, median survival time (MST), and percentage increased life span (\%ILS). MST for each group was noted and anticancer activity of the test compounds was compared with that of control group by measuring \%ILS [13].

MST $=($ Day of first death + day of last death $) / 2$

ILS (\%) $=([$ MST of treated group mice $/$ MST of control group mice $]-1)$ $\times 100$

The viability and non-viability of the cells were checked by trypan blue assay. The cells were stained with trypan blue $(0.4 \%$ in normal saline) dye. The cells that did not take up the dye were viable and those that took the dye were nonviable. These viable and non-viable cells were counted.

\section{Hematological and biochemical studies}

On the past day of the experiment, after an overnight fasting blood was collected through tail vein for the estimation of hemoglobin ( $\mathrm{Hb}$ ) level, red blood cell (RBC), white blood cell (WBC) counts, and biochemical parameters: Serum glutamate oxaloacetate transaminase, serum glutamate pyruvate transaminase (SGPT), alkaline phosphatase (ALP), total proteins, and albumin by standard procedures.

\section{Statistical analysis}

The results were computed using GRAPH PRISM PAD version 7 software, one-way ANOVA test followed by post hoc Tukey's multiple comparison tests were applied for analysis. Observations were expressed as mean \pm SEM. The differences between means were considered to be statistically significant at $\mathrm{p}<0.05$ ( $95 \%$ confidence individuals)

\section{RESULTS}

\section{Phytochemical screening test}

The freshly prepared extract of the leaves of A. salvifolium was subjected to phytochemical screening tests for the detection of various active constituents. The extract showed the presence of alkaloids, tannins, steroids, phenols, flavonoids, carbohydrates, and glycosides in crude ethanolic EASL as depicted in Table 1.

\section{Anticancer activity}

Toxicity evaluation

In the acute toxicity study, no mortality occurred within $72 \mathrm{~h}$ and till 14 days under the tested doses. The maximal tolerated dose of ethanolic extract of AP was found to be $>2000 \mathrm{mg} / \mathrm{kg}$. On the basis of toxicological data, therapeutic doses were selected (Tables 2 and 3).

\section{DISCUSSION}

Recently, the alternative cancer therapies with the herbal medicines are gaining importance even as adjuvant to the chemotherapeutic drugs

Table 1: Result of chemical group tests of the ethanolic EASI

\begin{tabular}{lllllllll}
\hline EE & Carbohydrates & Tannins & Flavonoid & Saponin & Phenols & Steroids & Alkaloids & Glycosides \\
\hline A. salvifolium & ++ & ++ & ++ & - & ++ & + & + & +++ \\
\hline
\end{tabular}

EASL: Extract of Alangium salvifolium leaves, EE: Ethanolic extract, (+): Present, (-): Absent, (+++): Reaction intensity is high, (++): Reaction intensity is medium, (+): Reaction intensity is normal 
Table 2: Effect of EASL on tumor growth response

\begin{tabular}{|c|c|c|c|c|c|}
\hline \multirow[t]{2}{*}{ Parameters } & \multirow[t]{2}{*}{ EAC control } & \multicolumn{4}{|l|}{ Test groups } \\
\hline & & I & II & III & IV \\
\hline Tumor volume (ml) & $6.5 \pm 0.92$ & $2.4 \pm 0.54^{* *}$ & $4.5 \pm 0.56^{*}$ & $3.8 \pm 0.63^{*}$ & $3.1 \pm 0.78^{*}$ \\
\hline MST (days) & $22.3 \pm 0.79$ & $52.4 \pm 3.8$ & $32.8 \pm 3.4$ & $39.5 \pm 1.45$ & $47.2 \pm 2.3$ \\
\hline$\%$ ILS & 0 & 134.97 & 47.08 & 77.13 & 111.65 \\
\hline Total tumor cell count $\left(\times 10^{7}\right.$ cells $\left./ \mathrm{ml}\right)$ & $12.2 \pm 0.65$ & $4.2 \pm 0.54^{* *}$ & $6.5 \pm 0.78^{*}$ & $5.4 \pm 0.9^{*}$ & $4.56 \pm 0.43^{* *}$ \\
\hline Non-viable cell count $\left(\times 10^{7}\right.$ cells $\left./ \mathrm{ml}\right)$ & $0.8 \pm 0.45$ & $2.6 \pm 0.33^{* *}$ & $1.55 \pm 0.76^{*}$ & $1.72 \pm 0.81^{*}$ & $1.9 \pm 0.28^{*}$ \\
\hline
\end{tabular}

Values are expressed as mean \pm SEM, I - standard (cisplatin $3.5 \mathrm{mg} / \mathrm{kg}$ ) + EAC, II - EASL (100 mg/kg p.o) + EAC, III - EASL (200 mg/kg p.o) + EAC, IV - combined group cisplatin (1.75 mg/kg i.p.) and EASL $(100 \mathrm{mg} / \mathrm{kg} \mathrm{p.o})+$ EAC. ${ }^{*} \mathrm{p}<0.05,{ }^{* *} \mathrm{p}<0.01$ compared to EAC control

Table 3: Effect of EASL on hematological and biochemical parameters

\begin{tabular}{|c|c|c|c|c|c|c|}
\hline \multirow[t]{2}{*}{ Parameters } & \multirow[t]{2}{*}{ Normal } & \multirow[t]{2}{*}{ EAC control } & \multicolumn{4}{|l|}{ Test groups } \\
\hline & & & I & II & III & IV \\
\hline Total RBC $\left(\times 10^{6}\right.$ cells $\left./ \mathrm{ml}\right)$ & $6.4 \pm 0.92$ & $3.2 \pm 0.23^{*}$ & $6.1 \pm 0.54^{b}$ & $4.3 \pm 0.56^{\mathrm{a}}$ & $5.1 \pm 0.63^{\mathrm{b}}$ & $5.8 \pm 0.78^{\mathrm{a}}$ \\
\hline Hemoglobin (Hb) (g\%) & $14.45 \pm 0.88$ & $6.3 \pm 0.79 * *$ & $11.4 \pm 3.8^{\mathrm{b}}$ & $9.8 \pm 3.4^{\mathrm{a}}$ & $10.5 \pm 1.45^{\mathrm{a}}$ & $11.8 \pm 2.3^{\mathrm{a}}$ \\
\hline Total proteins $(\mathrm{g} / \mathrm{dl})$ & $6.6 \pm 0.4$ & $3.3 \pm 0.5^{* *}$ & $5.8 \pm 0.97^{\mathrm{a}}$ & $5.0 \pm 0.8^{\mathrm{a}}$ & $5.2 \pm 0.3^{\mathrm{a}}$ & $6.0 \pm 0.56^{\mathrm{b}}$ \\
\hline Albumin (g/dl) & $1.9 \pm 0.1$ & $1.1 \pm 0.29^{* *}$ & $1.52 \pm 0.1^{\mathrm{b}}$ & $1.34 \pm 1.3^{\mathrm{a}}$ & $1.48 \pm 0.84^{\mathrm{a}}$ & $1.58 \pm 0.2^{\mathrm{b}}$ \\
\hline SGOT (IU/L) & $41 \pm 1.2$ & $72.2 \pm 2.65^{* *}$ & $53.2 \pm 1.54^{\mathrm{a}}$ & $67.5 \pm 1.78^{\mathrm{a}}$ & $60.4 \pm 1.9^{\mathrm{a}}$ & $56.56 \pm 1.43^{\mathrm{a}}$ \\
\hline SGPT (IU/L) & $45.7 \pm 2.2$ & $68.8 \pm 0.45^{* *}$ & $56.4 \pm 0.33^{\mathrm{b}}$ & $62.45 \pm 0.76^{\mathrm{a}}$ & $58.2 \pm 0.81^{\mathrm{a}}$ & $57.9 \pm 0.28^{\mathrm{a}}$ \\
\hline ALP (IU/L) & $87 \pm 2.45$ & $127 \pm 2.3^{*}$ & $108 \pm 2.4^{\mathrm{a}}$ & $120 \pm 1.8^{\mathrm{a}}$ & $114 \pm 2.3^{\mathrm{a}}$ & $117 \pm 1.7^{\mathrm{a}}$ \\
\hline
\end{tabular}

Values are expressed as mean \pm SEM, I - standard (cisplatin 3.5 mg/kg) + EAC, II - EASL (100 mg/kg p.o) + EAC, III - EASL (200 mg/kg p.o) + EAC, IV - combined group cisplatin (1.75 mg/kg i.p.) and EASL ( $100 \mathrm{mg} / \mathrm{kg}$ p.o) + EAC. ${ }^{*} \mathrm{p}<0.05,{ }^{* *} \mathrm{p}<0.01$ values are significantly different when compared to control (normal). ${ }^{\mathrm{p}}<<0.05$, ${ }^{\mathrm{b}} \mathrm{p}<0.01$ values are significantly different when compared to EAC control. SGOT: Serum glutamic oxaloacetic transaminase, SGPT: Serum glutamate pyruvate transaminase, ALP: Alkaline phosphatase

from the point of less toxic effects and cost benefits. In the present study, we evaluated the anticancer potential of $A$. salvifolium leaves which is used in ayurvedic system of medicine for various purposes.

The extract revealed the presence of various phytochemicals such as reducing sugars, flavonoids, phenols, tannins, steroids, alkaloids, and glycosides (Table 1). Previous articles have proved that leaves extract of A. salvifolium was safe up to the dose of $2000 \mathrm{mg} / \mathrm{kg}$ (p.o) body weight in mice [14]. Phytoconstituents like flavonoids, alkaloids, and steroids are known to possess anticancer activity, while flavonoids are shown to have antimalignant and antimutagenic properties [15]. In the present study, EASL has shown potent dose-dependent anticancer activity in EAC-bearing mice.

Treatment with EASL in the dose of 100 and $200 \mathrm{mg} / \mathrm{kg}$ body weight ILS and non-viable cell count and reduced the tumor volume and body weight significantly when compared to that of EAC control group (Table 2). Prolongation of life span and decrease in WBC cell count are reliable criteria for assessing the anticancer potential of any drug. Hence, it may be concluded that the extract by direct cytotoxic effects and by increasing the lifespan possess anticancer property. Myelosuppression and anemia are the major problems in cancer chemotherapy. Anemia in tumor-bearing mice may be due to iron deficiency, hemolytic, or myelopathic condition [16]. Treatment with EASL restored the Hb levels, RBC and WBC counts to near normal levels (Table 2), which indicates that the extract may possess protective effect on hematopoietic system.

Hepatotoxicity noted with anticancer chemotherapeutic agents may result due to their direct cytotoxic effects or due to their toxic metabolites. Elevated levels of biochemical parameters SGOT, SGPT, and ALP along with lowered levels of total proteins and albumin are noted in tumor-bearing mice [17]. In the present investigation, EASL restored these parameters toward normal levels, indicating hepatoprotective activity of EASL extract.

Previous studies have reported the significant anticancer activity of the crude extract of $A$. salvifolium flowers probably due to the presence of alkaloids, flavonoids, phenols, and terpenoids. Our study showing significant anticancer potential of ethanolic EASL is in concurrence with the study. The results of the present study are also consistent with the earlier report, which proved significant antitumor activity of the methanolic extract of A. salvifolium plant (200 and $400 \mathrm{mg} / \mathrm{kg}$ ) against Dalton's ascitic lymphoma. The anticancer activities of ethanolic EASL are probably due to the presence of flavonoids, phenols, tannins, steroids, and alkaloids.

\section{CONCLUSION}

The present study demonstrates the potent anticancer activity of A. salvifolium leaves extract. Further studies on the elucidation of its mechanism of action and the isolation of its active constituents may prove rewarding in cancer treatment.

\section{AUTHORS' CONTRIBUTION}

Authors Prathima C and Shashikumara are involved in conduct of experiments. Authors Prathima C and Thippeswamy T are involved in preparing of graphs, manuscript writing, and editing.

\section{CONFLICTS OF INTEREST}

Authors declare that they have no conflicts of interest.

\section{REFERENCES}

1. Dashora N, Sodde V, Bhagat J, Prabhu KS, Lobo R. Antitumor activity of Dendrophthoe falcate against Ehrlich ascites carcinoma in Swiss albino mice. Pharm Crops 2010;2:1-7.

2. American Cancer Society. Global Cancer Facts and Figures 2007. Atlanta, GA: American Cancer Society; 2007.

3. Lyon B. In: Levin BE, editor. World Cancer Report 2008. Geneva: IARC Press; 2008.

4. Yin SY, Wei WC, Jian FY, Yang NS. Therapeutic applications of herbal medicines for cancer patients. Evid Based Complement Alternat Med eCAM 2013;2013:302426.

5. Pearce A, Haas M, Viney R, Pearson SA, Haywood P, Brown C, et al. Incidence and severity of self-reported chemotherapy side effects in 
routine care: A prospective cohort study. PLoS One 2017;12:e0184360.

6. Anantharaju PG, Gowda PC, Vimalambike MG, Madhunapantula SV. An overview on the role of dietary phenolics for the treatment of cancers. Nutr J 2016;15:99.

7. Venkateshwarlu R, Raju AB, Yerragunta VG. Phytochemistry and pharmacology of Alangium salvifolium: A review. J Pharm Res 2011;4:1423-5.

8. Nahar L, Zahan R, Mosaddik A, Islam S, Haque A, Fazal A, et al. Antioxidant and antitumor activity of chloroform extract of Alangium salvifolium flowers. Phytopharmacology 2012;2:123-34.

9. Ravikumar AR, Madgaonkar V, Venkatesha RT, Bharathi R, Murthy KV. Potential cytotoxic drug effects of secondary metabolites derived from selected medicinal plants of Savanadurga forest in Karnataka. Int J Pharm Pharm Sci 2014;6:238-41.

10. Parameshwar P, Reddy YN. Protective role in-vitro free radical scavenging activities of Alangium salvifolium (linn) againest CCL4 induced hepatic damage in rats. Int J Pharm Pharm Sci 2015;7:447-52.

11. Srikanth P, Sudhakara K, Basha GG, Muruli K, kumar SA. Antiulcer effect of Alangium salvifolium ethanolic leaf extract on gastric lesion induced by ethanol rats. Asian J Pharm Clin Res 2011;4:112-4.

12. Kuttan G, Vasudevan DM, Kuttan R. Isolation and identification of a tumor reducing component from mistletoe extract (Iscador). Cancer Lett 1988;41:307-15

13. Gupta M, Mazumder UK, Rath N, Mukhopadhyay DK. Antitumor activity of methanol extract of Cassia fistula L. Seed against Ehrlich ascites carcinoma. J Ethnopharmacol 2000;72:151-6.

14. Shashikumara S, Prathima C, Sibgatullah M. Evaluation of antidepressant activity of ethanolic extract of Alangium salvifolium leaves in Swiss albino mice. Biomed Pharm J 2017;10:427-33.

15. Fotsis T, Pepper MS, Aktas E, Breit S, Rasku S, Adlercreutz H, et al. Flavonoids, dietary-derived inhibitors of cell proliferation and in vitro angiogenesis. Cancer Res 1997;57:2916-21.

16. Viral D, Shivanand P, Jivani N. Anticancer evaluation of Adiantum venustum Don. J Young Pharm 2011;3:48-54.

17. Marappan S, Subramaniyan A. Antitumor activity of methanolic extract of Cynodon dactylon leaves against Ehrlich ascites induced carcinoma in mice. J Adv Sci Res 2012;3:105-8. 